\title{
БЕЗПЕКА ПРАЦІ ТА ОХОРОНА ЗДОРОВ'Я МЕДИЧНИХ СЕСТЕР ЗА УМОВ ПАНДЕМІї COVID-19
}

\author{
О. Буряк, О. Димчук, Т. Прокопенко, О. Колісник \\ Тернопільський національний медичний університет \\ імені І. Я. Горбачевського МОЗ Украӥни
}

У статті проаналізовано і підсумовано дані щодо безпеки праці та охорони здоров’я медичного персоналу за умов пандемії. У часи боротьби з коронавірусом про роль медсестер згадують все частіше. Адже ці медичні працівники найближче спілкуються з хворими на COVID-19.

\section{OCCUPATIONAL SAFETY AND NURSE HEALTH IN THE CONVENTION OF THE COVID-19 PANDEMIC}

\author{
O. Buriak, O. Dymchuk, T. Prokopenko, O. Kolisnyk
}

\section{Horbachevsky Ternopil National Medical University}

\begin{abstract}
The article analyzes and summarizes the data on occupational safety and health of medical personnel in a pandemic. The role of nurses is increasingly mentioned in the fight against coronavirus. After all, these health professionals communicate most closely with patients with COVID-19.
\end{abstract}

Вступ. У боротьбі з коронавірусною пандемією, іï поширенням та проявами в кожній постраждалій країні світу, в тому числі Україні, передову лінію оборони забезпечують медичні працівники. В історії світу є чимало прикладів, коли власне частка інфікованих медичних працівників у популяції захворілих $\epsilon$ найбільшою. Зокрема, дані ВООЗ свідчать про те, що у 2002-2003 рр. під час спалаху епідемії SARS медичні працівники становили 21 \% від заражених осіб [10].

Медичний персонал є найпершою категорією ризику зараження коронавірусом SARS-CoV-2 і розвитку коронавірусної хвороби (COVID-19) незалежно від віку, наявності супутніх хвороб та імунного статусу медичних працівників, особливо серед тих, хто лікує пацієнтів з COVID-19. В Італії серед усіх людей, у яких підтвердили наявність коронавірусу, було 6200 медиків. В Іспанії їх налічується приблизно 6500, що становить 12 \% заражень. У Китаї, за підрахунками, на початку березня були виявлені зараження в орієнтовно 3300 медичних працівників. У цілому приблизно 4-12 \% підтверджених випадків коро-

(C) О. Буряк, О. Димчук, Т. Прокопенко, О. Колісник, 2021 навірусної хвороби у світі становлять медики [1]. Ризики, з якими стикаються медичні працівники, які здійснюють менеджмент інфікованих пацієнтів та беруть участь у ліквідації пандемічного поширення COVID-19, змушують ставити акценти на профілактичних заходах, спрямованих на зниження ризику інфікування для працівників системи охорони здоров'я.

Основна частина. Характеризуючи ризики і даючи їм кількісну оцінку, варто констатувати, що умови праці медичного персоналу, який безпосередньо задіяний у боротьбі з епідемією COVID-19 та лікуванні пацієнтів, формуються сукупністю фізичних, хімічних, психофізіологічних та біологічних факторів, серед яких визначальна роль належить біологічному чиннику - коронавірусу SARS-CoV-2 [3].

Історичні згадки про поширення COVID-19:

- 31 грудня 2019 р. - перше повідомлення про SARS-CoV-2 у м. Ухань (Китай);

- 13 січня 2020 р. - Всесвітня організація охорони здоров'я (ВООЗ) опублікувала перший протокол дослідження методом полімеразної ланцюгової реакції (ПЛР); 
- 25 січня 2020 р. - опубліковано перші рекомендації щодо менеджменту пацієнтів, інфікованих SARS-CoV-2;

- 11 березня 2020 р. - ВООЗ оголосила COVID-19 пандемією, розпочато світовий локдаун та закрито кордони держав;

- 4 червня 2020 р. - перше рандомізоване клінічне дослідження щодо лікування COVID-19;

- 3 липня 2020 р. - Європейський Союз схвалив перший препарат, показаний для лікування COVID-19, - «Ремдесивір»;

- 8 грудня 2020 р. - проведено першу вакцинацію.

Профілактика та раннє лікування пацієнтів, інфікованих SARS-CoV-2, дуже стрімко змінювалися, що пов'язано з дуже швидким проведенням та оприлюдненням даних клінічних досліджень, оскільки не лише клініцисти, а й мікробіологи, епідеміологи, діагности, біологи, біотехнологи та інші фахівці проводили власні дослідження щодо оцінки «феномена» COVID-19. За останні 2 місяці в Національному центрі біотехнологічної інформації (National Center for Biotechnology Information - NCBI) збільшилася кількість нових джерел на 75 тис., включно з клінічними дослідженнями, метааналізами та систематичними оглядами, що вказує на вражаючу численність проведених наукових досліджень. Водночас нині наявна недостатня кількість даних щодо медикаментозної профілактики COVID-19 [11, 12].

Підбиваючи підсумки півторарічної пандемії, коли після перших повідомлень про появу нового штаму коронавірусу минув значний період, та, незважаючи на рекордно швидке налагодження у світі протиепідемічних, діагностичних, лікувальних та профілактичних заходів, поширеність COVID-19 та смертність від його ускладнень продовжують зростати.

В Україні виявлення та лікування хворих на COVID-19, а також захист медичного персоналу здійснюються відповідно до наказів МОЗ України: «Про затвердження та впровадження стандартів медичної допомоги при коронавірусній хворобі (COVID-19)» від 25.02.2020 р. № 552; «Організація надання медичної допомоги хворим на коронавірусну хворобу (COVID-19)» від 28.03.2020 р. № 722; «Про затвердження протоколу «Надання медичної допомоги для лікування коронавірусної хвороби (COVID-19)» від 02.04.2020 р. № 762; «Про внесення змін до протоколу «Надання медичної допомоги для лікування коронавірусної хвороби (COVID-19)» від 06.04.2021 р. № $638[5,6]$.
Серед майже 40 тис. існуючих на сьогодні професій медичні працівники займають особливу соціальну нішу, оскільки специфікація їх трудової діяльності пов'язана з впливом професійних факторів ризику, здатних викликати захворювання, призводити до втрати працездатності, інвалідності, а в деяких випадках бути безпосередньою загрозою для життя. Медичні працівники завжди працювали в умовах надзвичайно високого професійного ризику, але пандемія COVID-19 внесла свої корективи і в десятки разів збільшила й так високий ризик у цій когорті працівників. Сучасні дані щодо диспансеризації медичних працівників свідчать про те, що через шкідливі фактори виробничого середовища лише один з 5 медичних працівників $\epsilon$ практично здоровим, 2/3 із загальної кількості потребують додаткового обстеження та амбулаторного лікування, а близько 2 \% - обстеження і лікування в умовах стаціонару [4].

Відповідно до сучасних даних, 1-ше місце у структурі професійних хвороб займають саме інфекційні, частота яких становить 75-83 \%. До основних нозологічних форм належать туберкульоз органів дихання (50,48 \%) та вірусний гепатит В (15,65 \%). За ними слідують алергічні захворювання, інтоксикації та захворювання опорно-рухового апарату. Однак на сьогодні найбільшу небезпеку для медичних фахівців становить саме COVID-19, що підтверджено відповідними нормативними документами. Так, 23 березня 2020 р. Міжнародна організація праці (Organization) оприлюднила нормативний документ «Основні положення міжнародних трудових стандартів стосовно спалаху COVID-19», в якому зазначено, що внаслідок пандемії було втрачено 25 млн робочих місць, включно і медичних працівників, у всьому світі [10]. Крім того, у документі зазначено, що COVID-19 може розглядатися як професійне захворювання саме у медичних та соціальних працівників за умови, якщо інфікування відбулося внаслідок професійного контакту. І якщо перші дані з Китаю повідомляли, що найбільш значне поширення SARS-CoV-2 отримав на початку пандемії серед працівників торгівлі, то медичні працівники стали наступною професійною когортою з високим ступенем ризику інфікування. На сьогодні у світі COVID-19 визнано як професійне захворювання, зокрема в Італії, Німеччині, Південно-Африканській Республіці, Канаді та Бельгії, а 27 квітня 2020 р. Міжнародна організація профспілок (International Trade Union Confederation) в міжнародний день пам'яті робочих 
закликала класифікувати COVID-19 як професійне захворювання з метою забезпечення медичних працівників надійним соціальним захистом, доступу до надання медичної допомоги та компенсації за втрачене здоров'я.

Окремим тезисом слугує те, що ризик зараження і захворюваності медичного персоналу на коронавірусну хворобу COVID-19 існує на всіх етапах надання медичної допомоги - на поліклінічному, догоспітальному, стаціонарному. Без сумніву, найбільшого ризику заразитися й захворіти за умов пандемії COVID-19 зазнає медичний персонал стаціонарних інфекційних лікарень та відділень [4].

Зокрема, у приймальному відділенні/пропускнику інфекційного стаціонару медичні працівники мають високий ризик зараження через необхідність прийому значного числа пацієнтів як потенційних джерел інфекції. При проведенні об'єктивного обстеження з оглядом ротоглотки, інших обстежень, що передбачають контакт із хворим на відстані меншій ніж 1 метр (пальпація, перкусія, аускультація, взяття зразків зі слизової носа, ротоглотки) - ризик зараження вкрай високий. Медичні сестри пропускників здійснюють безконтактну термометрію з невеликої відстані, вимірювання артеріального тиску, взяття з носових ходів та ротоглотки необхідних мазків. Менший ризик мають санітарні працівники пропускників, які проводять поточну дезінфекцію після прийому хворого, відправляють його верхній одяг до дезінфекційної камери.

Лікарі, середній та молодший медичний персонал інфекційного відділення також мають ризик зараження, але дещо менший порівняно з працівниками приймального відділення. У разі необхідності уточнення стану хворого, який перебуває в боксі чи ізольованій палаті, можливе використання візуального контролю через вікно боксу та доповнення його телефонним зв'язком. Для середніх і молодших медичних працівників існує ризик зараження під час проведення ін'єкцій, інших діагностичних та лікувальних процедур, а також поточної та заключної дезінфекції.

Проте найвищий ризик захворювання і зараження медперсоналу на COVID-19 існує у відділеннях інтенсивної терапії та реанімації, де здійснюють інтенсивне лікування (неінвазивна та інвазивна киснева підтримка, парентеральне введення препаратів тощо). Тривале ліжкове перебування хворих, які $є$ інтенсивними джерелами виділення вірусу, призводить до підвищення забруднення збудником по- вітря. Здійснення персоналом багатьох інвазивних медичних процедур (проведення ларингоскопії для введення дихальної трубки з метою підключення до апарата штучної вентиляції легень (ШВЛ), трахеотомії зі встановленням трахеостоми з цією метою; бронхіальний лаваж, бронхоскопія, меншою мірою венопункція, катетеризація підключичної артерії тощо) також супроводжується підвищеним ризиком зараження лікарів-реаніматологів, медичних сестер реанімаційного відділення, санітарок [9].

За ступенем вираження ризику зараження і захворювання на COVID-19 категорії медичних працівників можна ранжувати в такій послідовності: лікарі-реаніматологи, медичні сестри реанімаційних відділень, санітарки реанімаційних відділень, лікарі пропускників інфекційних відділень, лікарі поліклінік, які здійснюють огляд хворого на відстані меншій ніж 1 метр, лікарі-паталогоанатоми, лікарі-лаборанти, лікарі-епідеміологи [7].

Із фізіолого-гігієнічних позицій робота медичного персоналу, який працює в умовах подолання коронавірусної епідемії COVID-19, відповідно до критеріїв «Гігієнічної класифікації праці за показниками шкідливості та небезпечності факторів виробничого процесу, важкості і напруженості праці» (затв. наказом МО3 України від 08.04.2014 р. № 248), за умовами праці належить до небезпечної (екстремальної) - 4 класу. Варто зазначити, що ризик небезпечності за індексом розвитку професійного захворювання для цього класу робіт перевищує 1. Для порівняння: зазначений індекс при проведенні робіт у шкідливих умовах (клас 3) становить 0,05-1,0; допустимих (клас 2) менше 0,05; оптимальних (клас 1) - 0. Тобто ризик розвитку професійного захворювання на COVID-19 у медичного персоналу, не захищеного спеціальними засобами, є надзвичайно високим та вірогідним.

Для захисту від зараження і захворювання медичного персоналу на COVID-19 наказами MO3 України, про які згадувалося вище, передбачено нормативне забезпечення сертифікованими засобами індивідуального захисту (3І3) при виконанні всіх видів професійної діяльності на кожному етапі надання медичної допомоги. Передбачено захист кожного медичного працівника з використанням широкого арсеналу 3Із: від медичних масок, рукавичок та окулярів до щитків для обличчя, захисних окулярів, халатів одноразового використання, захисних комбінезонів (Chemsafe C1, AllSet, Tyvek тощо); протиаерозольних респіраторів: сертифікованого Націо- 
нальним інститутом США з охорони праці промислового гігієнічного респіратора N95 або Європейським Союзом респіратора FFP2 чи будь-якого іншого сертифікованого респіратора з еквівалентними захисними властивостями.

На захист медичних працівників за умов боротьби з епідемією COVID-19 спрямовано листи МО3 України (від 06.04.2020 р. № 05.1-08/9241/2-20) та Державної служби України з питань праці (від 07.04.2020 р. № 2480/1/35-20), які стосуються проведення розслідування лабораторно підтверджених випадків COVID-19 у медичних працівників, пов'язаних із виконанням професійних обов'язків. Зокрема, в листах МОЗ і Держпраці України зазначено, що лабораторно підтверджені випадки інфікування COVID-19 медичних та інших працівників, що пов'язані з виконанням професійних обов'язків за умов підвищеного ризику зараження на COVID-19, підлягають розслідуванню як випадки гострого професійного захворювання відповідно до вимог Порядку розслідування та обліку нещасних випадків, професійних захворювань та аварій на виробництві, затвердженого Постановою Кабінету Міністрів України від 17 квітня 2019 р. № 337. Тобто лабораторно підтверджений професійно зумовлений випадок COVID-19 у медичного працівника діагностують і обліковують як гостре професійне захворювання «Коронавірусна хвороба COVID-19» з відшкодуванням усіх передбачених чинним законодавством для випадку професійного захворювання збитків.

Міністерство охорони здоров'я для матеріального стимулювання медичного персоналу проводить грошову доплату в розмірі трьох окладів (тарифних ставок) за березень поточного року (наказ МОЗ України від 02.04.2020 р. № 768). Доплата передбачена медичним та іншим працівникам, які безпосередньо задіяні у ліквідації епідемії та здійсненні заходів із запобігання поширенню гострої респіраторної хвороби COVID-19, а також у лікуванні пацієнтів із випадками гострої респіраторної хвороби COVID-19, згідно з персональним переліком, який затверджує керівник медичного закладу.

На сьогодні медичні установи, визначені для лікування хворих на COVID-19, дотримуючись виконання протиепідемічних і санітарно-гігієнічних вимог внутрішньолікарняного режиму, забезпечуючи безпеку праці медичного персоналу і надаючи необхідну медичну допомогу хворим на COVID-19, функціонують у штатному режимі.
Проте варто зазначити, що стримувана соціальною ізоляцією населення захворюваність на COVID-19 як серед громадян, так і медичних працівників прямолінійно не знижується. А тому можна вважати, що захищеність медиків $\epsilon$ недостатньою. Як приклад, можна навести архівні епідеміологічні дані $з$ сайта Державної служби України з питань праці, що станом на 14 квітня 2020 р. діагноз гострого професійного захворювання COVID-19 був встановлений 98 медичним працівникам (13 квітня їх було 69), а на 15 квітня їх стало 112 [8]. Ці об'єктивні офіційні показники захворюваності медичного персоналу на COVID-19, особливо професійної захворюваності, безумовно свідчать про недостатню захищеність лікарів, медсестер і санітарок на їхніх робочих місцях, зокрема засобами індивідуального захисту. Якщо обладнанням лікарні по Україні в цілому забезпечені на 71,2 \%, а персоналом - на 76,7 \%, то засобами індивідуального захисту - лише на 59,4 \%. Найнижчі показники - в Івано-Франківській (47,04 \%), Волинській (53,3 \%), Тернопільській (53,63 \%) областях (https://covid19.gov.ua/analitichni-paneli-dashbordy).

Видання «Bloomberg» зазначає з цього приводу, що за умов коронавірусної епідемії COVID-19 у Китаї найсерйознішою помилкою лікарі Китаю визнали допуск до догляду за хворими пацієнтами не досить захищених медичних працівників. Через це зріс рівень захворюваності на COVID-19 серед лікарів і медсестер. Наводять приклад, що в Ухані в перші тижні боротьби з коронавірусом заразилися тисячі медпрацівників. Щонайменше 46 із них померли, оскільки не вистачало засобів захисту. Багато китайських лікарів і медсестер розповідали, що доводилося споживати їжу лише один раз на день, щоб не користуватися туалетом, після якого потрібно було утилізувати захисний костюм, а замінити його на той час іншим не було змоги.

Необхідно бути готовими до того, що в разі подальшого розвитку епідемічного процесу та різкого підвищення захворюваності населення на COVID-19 може скластися невідповідність між чисельністю контингентів, які потребують медико-санітарної допомоги, та наявними силами і засобами охорони здоров'я. Один із шляхів, який використовують для подолання цієї невідповідності, полягає у використанні надмірної ненормованої праці медичного персоналу, який стає за таких умов ще більш вразливою групою ризику зараження вірусом SARS-CoV-2. Про це свідчить досвід боротьби з COVID-19 Китаю, Іспа- 
нії, США. Високий ризик заразитися самим і членам сім'ї, недостатня кількість та низька якість засобів індивідуального захисту, понаднормовий робочий день, відсутність належних умов відпочинку - всі ці фактори зумовлюють зростання й без того значного нервово-емоційного напруження медичного персоналу, розвитку стану гострої втоми, втрати працездатності та психологічного виснаження. За таких екстремальних умов навіть незначні фізіологогігієнічні хиби засобів індивідуального захисту перетворюються на великі проблеми, в тому числі через спробу недопущення інфікованого повітря через позареспіраторний чи позащитковий простір. Перепрофілювання соматичних відділень та лікарень на інфекційні, що неминуче відбувається в такий період, тягне за собою можливе забруднення інфекційним агентом об'єктів довкілля через відсутність відповідних очисних пристроїв і засобів, які передбачені для інфекційних лікарень відповідно до вимог Державних будівельних норм ДБН 3.2.2-10-2001 [2].

Запровадження в країні карантинних заходів, насамперед соціальної ізоляції, стримувало розвиток епідемії та різкого зростання захворюваності на COVID-19 за умов відсутності специфічної профілактики і специфічного лікування. Проте, якби соціальна ізоляція була поєднана з ПлР-тестуванням, то вона 6 у рази посилила протиепідемічні ефекти, оскільки це сприяло би більш ранньому активному виявленню інфікованих осіб.

В Україні завдяки старанням МОЗ створюється система реабілітації пацієнтів, які перехворіли на коронавірусну хворобу [6]. У такий спосіб, завдяки наявній мережі лікувальних закладів та зважаючи на всесвітній досвід, пацієнти за направленням сімей- ного лікаря можуть отримувати певний обсяг постковідної реабілітації в Україні. 331 грудня 2020 р. набув чинності Закон України «Про реабілітацію у сфері охорони здоров'я», який забезпечив законодавче підґрунтя для впровадження сучасних підходів до надання реабілітаційної допомоги у сфері охорони здоров'я в Україні. Загалом за період квітень 2020 р. - березень 2021 р. стаціонарну допомогу в лікарнях отримали майже 435 тис. пацієнтів із коронавірусною хворобою, з яких майже 18 \% лікувалися в умовах інтенсивної терапії.

Розроблені Стандарти медичної допомоги «Реабілітація пацієнтів з коронавірусною хворобою (COVID-19) та реконвалесцентів» надіслали в регіональні департаменти охорони здоров'я для обговорення і найближчим часом затвердять у відповідних підрозділах і відомствах [6].

Завдяки чіткій стратегії та вивіреним діям МОЗ українці змогли пережити пік третьої хвилі пандемії без паніки та з мінімальними обмеженнями.

Висновки. Система охорони здоров'я, медичні працівники, яких пандемія COVID-19 наздогнала на стадії реформування, у цій складній і напруженій боротьбі за життя проявляють героїчний характер та витривалість. Варто врахувати допущені помилки та прорахунки, а також не лише світовий, а й кращий вітчизняний досвід на шляху до подальших змін при побудові нової моделі охорони здоров'я. Стабілізація ситуації із коронавірусною хворобою в Україні залежить від функціонування системи надання якісної медичної та реабілітаційної допомоги в закладах охорони здоров'я зі залученням повного складу медичних фахівців.

4. Жарікова Ю. В. Нова коронавірусна хвороба та інші глобальні виклики в інфектології [Електронний ресурс] / Ю. В. Жарікова // Український медичний часопис. - 2021. Режим доступу : www.umj.com.ua.

5. Про внесення змін до протоколу «Надання медичної допомоги для лікування коронавірусної хвороби (COVID-19) : наказ Міністерства охорони здоров'я України від 06 квітня 2021 р. № 638.

6. Про затвердження Протоколу надання реабілітаційної допомоги пацієнтам з коронавірусною хворобою (COVID-19) та реконвалесцентам : наказ Міністерства охорони здоров'я України від 20 квітня 2021 р. № 771. 
7. WHO (2021) COVID-19: Occupational health and safety for health workers. https://www.who.int/publications/i/item/ WHO-2019-nCoV-HCW_advice-2021.1.

8. URL : https://dsp.gov.ua/operativna-informaciacovid19/.

9. WHO (2020) Prevention, identification and management of health worker infection in the context of COVID-19. COVID-19: Essential health services, Oct 30. https://www. who.int/publications/i/item/10665-336265.

10. International Labour Organization (2010) ILO List of Occupational Diseases. Geneva : International Labour
Organization https://www.ilo.org/wcmsp5/groups/public/--ed_protect/---protrav/---safework/documents/publication/ wcms_125137.pdf.

11. IASC (2020) Public health and social measures for COVID-19 preparedness and response in low capacity and humanitarian settings. Version 1, May.

12. Kupferschmidt K. Race to find COVID-19 treatments accelerates / K. Kupferschmidt, J. Cohen // Science. 2020. - No. 367 (6485). - P. 1412-1413. DOI: 10.1126/ science.367.6485.1412. 